\title{
ZONASI PENURUNAN MUKA AIR TANAH DI WILAYAH PESISIR BERDASARKAN TEKNIK GEOFISIKA GAYABERAT MIKRO 4D (STUDI KASUS: DAERAH INDUSTRI KALIGAWE - SEMARANG)
}

\author{
ZONATION OF GROUND WATER DECREASE IN THE COASTAL AREA \\ BASED ON GEOPHYSICAL TECHNIQUES OF 4D MICROGRAVITY \\ (CASE STUDY: KALIGAWE INDUSTRIAL AREA - SEMARANG)
}

\author{
Dino Gunawan Pryambodo ${ }^{1}$ dan Supriyadi ${ }^{2)}$ \\ ${ }^{1)}$ Pusat Penelitian dan Pengembangan Sumberdaya Laut dan Pesisir \\ Balitbang KP, KKP \\ Jl. Pasir putih 1, Ancol Timur Jakarta 14430, \\ Telp: (021) 64713850 \\ e-mail : dino@kkp.go.id \\ 2)Jurusan Fisika, Universitas Negeri Semarang, Semarang
}

Diterima tangga: 17 Januari 2015, diterima setelah perbaikan12 Januari 2017 disetuji tanggal:16 Januari 2017

\begin{abstract}
ABSTRAK
Difisit airtanah menjadi masalah di kota-kota besar yang berada di wilayah pesisir, hal ini dipicu dengan adanya pengambilan airtanah yang tidak terkendali sehingga menimbulkan dampak krisis airtanah yang di tandai dengan menurunnya muka airtanah dan terjadinya amblesan tanah. Zonasi penurunan muka airtanah di kawasan industri Kaligawe, pesisir Semarang, dengan menggunakan teknik geofisika gayaberat mikro 4D dan gradien vertikal 4D serta dibantu dengan leveling untuk melihat amblesan tanah yang terjadi di daerah penelitian. Pengukuran dilakukan sebanyak dua kali, yaitu pada bulan Juni 2004 dan Nopember 2005 dalam jarak rentang waktu 16 bulan dengan 47 stasiun pengamatan. Disimpulkan bahwa hampir $70 \%$ daerah penelitian mengalami penurunan muka airtanah dan amblesan dan hal itu didukung dengan adanya penurunan muka airtanah yang terpantau dari beberapa sumur pantau yang berada di sekitar daerah penelitian.
\end{abstract}

Kata kunci : Teknik geofisika, penurunan muka airtanah, Daerah industri Kaligawe, Pesisir Semarang, Metode gayaberat mikro 4D

\begin{abstract}
Groundwater deficit is a problem for big city located in coastal areas, it is triggered by uncontrolled groundwater extraction generating groundwater crisis which is indicated by decreasing groundwater level and land subsidence. Zonation of decrease groundwater level in industrial area Kaligawe, coastal Semarang, using geophysical technique of 4D microgravity and 4D vertical gradient as well as assisted with leveling to observe the land subsidence occurred in the study area. The measurement is done twice, i.e. in June 2004 - November 2005 (in the range of 16 months period), and 47 observation stations. It was concluded that almost $70 \%$ of the study area has decreased groundwater level and subsidence where it is supported by the presence of decrease groundwater level observed from several monitoring wells located around the area of research.
\end{abstract}

Keywords: Geophysical technique, decrease groundwater level, Kaligawe industrial zone, Coastal zone of Semarang, 4D microgravity method 


\section{PENDAHULUAN}

Kekurangan atau difisit air bersih menjadi masalah yang besar bagi kota-kota besar yang berada di wilayah pesisir. Pengurangan jumlah air tanah sebagai pengisi dari akuifer mengakibatkan terjadinya penurunan muka air tanah, penurunan muka air tanah biasanya diikuti terjadinya penurunan muka tanah dan untuk daerah pesisir Semarang sebesar $15 \mathrm{~cm} /$ tahun [1], proses penurunan muka tanah ini akan menyebabkan masuknya air laut ke dataran ketika terjadi pasang seperti yang terjadi di daerah Semarang. Daerah industri Kaligawe Semarang dipilih sebagai lokasi penelitian karena daerah ini merupakan daerah industri yang setiap harinya memerlukan banyak air tanah dan berada di wilayah pesisir.

Teknik geofisika dengan metode gayaberat mikro 4D dipilih karena ramah lingkungan dalam hal pengambilan datanya, metode ini merupakan pengembangan dari metode gravitasi dalam geofisika eksplorasi dengan dimensi keempat adalah waktu. Prinsip dari metode ini adalah pengukuran gravitasi secara berulang baik harian, mingguan, bulanan maupun tahunan dengan mengunakan gravitymeter yang teliti dalam orde microGal. Metoda gayaberat mikro sangat sensitif terhadap perubahan densitas bawah permukaan secara lokal ataupun regional. Pengurangan massa pada akuifer memberikan pola perubahan gaya berat negatif, sedangkan penambahan massa pada akuifer memberikan pola perubahan gayaberat positif. Perubahan massa pada akuifer air tanah sangat kecil sehingga penggunaan metoda gayaberat mikro (microgravity) yang dilakukan secara berkesinambungan dengan periode tertentu sangat diperlukan guna mengetahui perubahan densitas pada suatu akuifer.

Lokasi penelitian berada di daerah Industri Kaligawe - Semarang (Gambar 1), secara geografis daerah ini terletak pada koordinat $110^{\circ} 26^{\prime} 51,96314^{\prime \prime} \quad-110^{\circ} 27 ' 50,66908^{\prime \prime}$ Bujur Timur dan 6057'17,74590" - 657'56,75530" Lintang Selatan. Lokasi daerah penelitian berada di Semarang Utara yang termasuk dalam daerah aluvial pantai Semarang. Daerah aluvial pantai Semarang adalah daerah yang ada di bagian utara, dan di apit oleh bukit candi di sebelah selatan dan laut Jawa di sebelah utara. Daerah aluvial pantai yang membujur dari arah barat-timur sepanjang pantai utara Jawa. Lebar dataran ini antara 3-4 $\mathrm{km}$, tetapi di antara Weleri dan Kaliwungu (muara Kali Bodri) lebarnya mencapai 16 km [2].

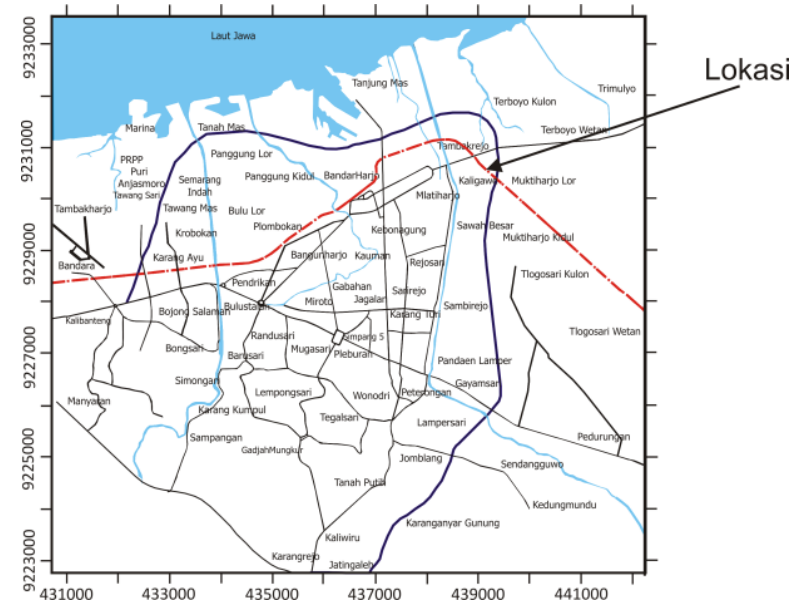

Gambar 1. Lokasi daerah penelitian

Pengambilan Air Tanah Sumur bor pertama di Semarang dibuat pada jaman pemerintahan Belanda terletak di Fort Wlhelm (Pelabuhan Tanjung Mas) pada tahun 1842 [3], kemudian pada Tahun 1900 terdapat 16 buah sumur bor, pada tahun 1990 menjadi 260 buah dan tahun 2003 meningkat menjadi 1.194 buah sumur bor, sehingga selama lebih kurang 13 tahun telah terjadi peningkatan pemanfaatan air tanah dari sumur bor sebanyak $459 \%$ [4].

Pemanfaatan air tanah yang dianggap cukup berarti di mulai pada tahun 1900 (Gambar 2), dengan pengambilan sebesar $1.300 \mathrm{~m}^{3}$ /hari dari 16 buah sumur bor. Jumlah pengambilan meningkat menjadi $1.610 \mathrm{~m}^{3} /$ hari pada tahun 1932 dengan jumlah sumur 28 buah. Jumlah pengambilan meningkat terus menjadi 37.460 $\mathrm{m}^{3} /$ hari pada tahun 1982 dengan jumlah sumur 127 buah. Pada tahun 1995, jumlah sumur tercatat resmi sebanyak 316 buah dengan pengambilan sekitar $74.130 \mathrm{~m}^{3} /$ hari [5].

Pemantauan muka air tanah di daerah Semarang selama ini hanya diamati dengan sumur bor pantau yang telah dilakukan sejak tahun 1952 oleh Direktorat Geologi Tata Lingkungan Bandung (Gambar 3) [6], dari hasil pemantauan menunjukkan kecenderungan terjadinya penurunan muka air tanah di daerah Semarang mencapai $1,5 \mathrm{~m} /$ tahun. Adanya penurunan muka air tanah memungkinkan untuk dibuat peta zonasi akibat dari penurunan muka air tanahnya di daerah Semarang. 


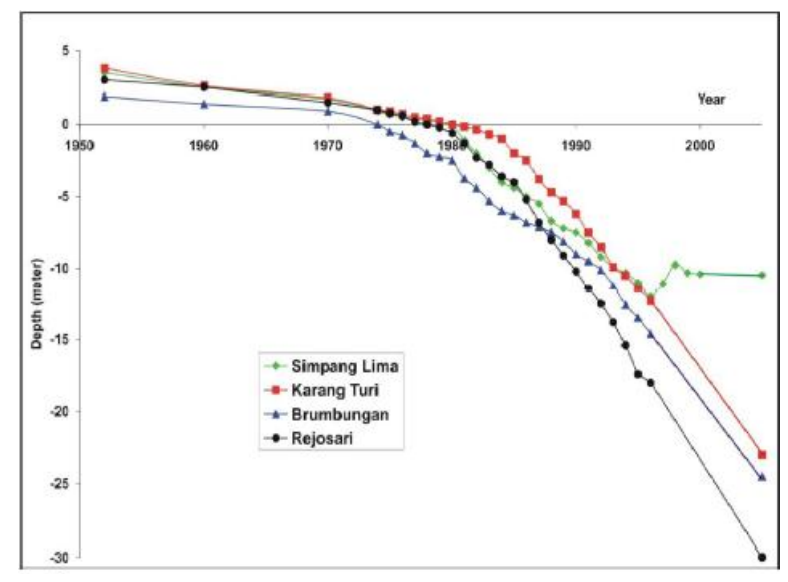

Gambar 3. Penurunan muka air tanah pada sumur pantau Karangturi, Simpanglima, Brumbangan dan Rejosari dari tahun 1952 - 2000 [7]

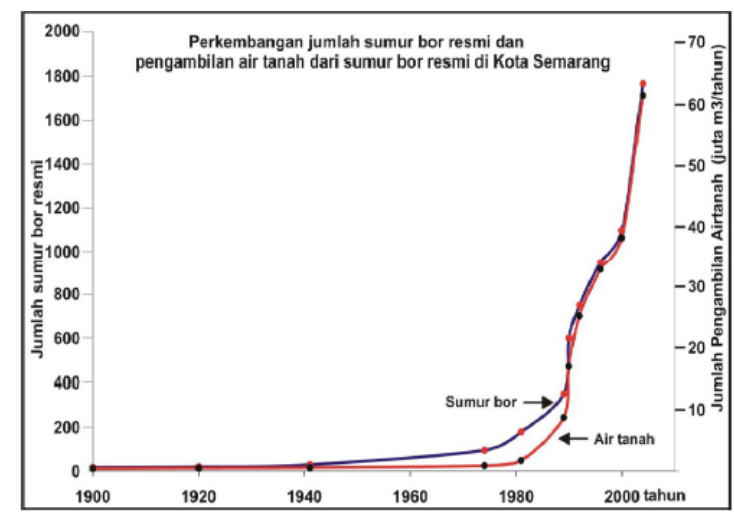

Gambar 2. Jumlah sumur bor dan pengambilan air tanah kota Semarang [5].

Penulisan ini dibatasi pada analisa perubahan gayaberat mikro 4D, gradien vertikal gayaberat 4D dan data penurunan muka tanah yang terjadi (amblesan) di daerah industri Kaligawe Semarang pada periode tersebut. Untuk

\section{BAHAN DAN METODE}

Pengukuran gayaberat-mikro 4D di daerah Industri Kaligawe - Semarang telah dilakukan sebanyak 2 kali mulai Juni 2004 dan Nopember 2005 dalam jarak rentang waktu 16 bulan dengan jumlah stasiun titik amat sebanyak 47 stasiun. Pengukuran gayaberat di lapangan menggunakan gravimeter Lacoste \& Romberg tipe G1158 [8] (Gambar 4) yang dilengkapi alliod system dengan ketelitian 5 mgal, sedangkan untuk pengukuran mengetahui zonasi perubahan muka air tanah dan membuat peta zonasi penurunan muka air tanah berdasarkan data geofisika (gayaberat mikro 4D, gradien vertikal gayaberat $4 \mathrm{D}$ ) tersebut di daerah penelitian

pasang surut secara kontinyu di base station digunakan gravimeter Lacoste \& Romberg tipe G508 yang dilengkapi system umpan balik elektronik dan terhubung dengan komputer. Pengukuran gayaberat menggunakan metode looping dengan titik ikat gayaberat (base) yang terletak di Taman Diponegoro Semarang. Pengukuran gayaberat tiap periode dilakukan dengan urutan pengukuran yang tetap.

Beberapa hal yang perlu diperhatikan pada saat melakukan pengukuran gayaberat adalah pertama, pemilihan gravitymeter yang akan digunakan.

Zonasi Penurunan Muka Air Tanah di Wilayah Pesisir Berdasarkan Teknik Geofisika Gaya berat Mikro 4D (Studi Kasus: Daerah Industri Kaligawe - Semarang) - Dino Gunawan Pryambodo dan Supriyadi 
Kedua, melakukan koreksi pasang surut yang diukur secara langsung. Ketiga, pemilihan titik ikat gayaberat (titik referensi atau base) harus memenuhi kreteria tidak mengalami amblesan, tidak terjadi penurunan muka air tanah dan jauh dari getaran di titik tersebut. Keempat, mendiskripsikan titik pengukuran gayaberat. Pada saat melakukan pengukuran gayaberat tiap periode, kondisi titik amat dan sekitarnya harus dicatat. Kelima, pengambilan data gayaberat dengan cara looping dan urutan pengambilan data tiap periode pengukuran harus tetap. Keenam, mempertimbangkan waktu pengukuran mengingat bahwa alat gravitymeter yang digunakan mempunyai sensivitas yang tinggi, maka pengukuran harus memperhatikan ada tidaknya goncangan yang terjadi [9].

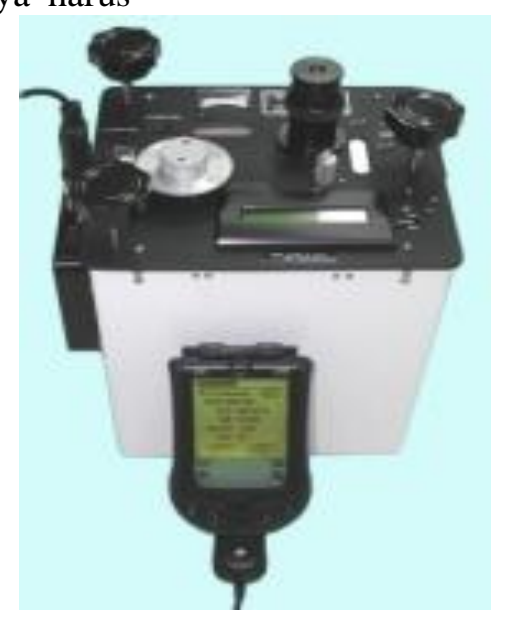

Gambar 4. Gravitymeter LaCoste and Romberg tipe G1158 [8].

Respon gayaberat akibat perubahan muka air tanah dapat dihitung menggunakan pendekatan koreksi slab Bouguer tak hingga dengan memasukkan faktor porositas [10] :

$$
\Delta g=2 \pi G \phi \rho_{w} \Delta h
$$

Perubahan kedalaman muka air tanah pada suatu tempat dipengaruhi oleh : musim, curah hujan,

$$
\left(g_{o b s(2)}-g_{o b s(1)}\right)=\left(G \int_{0}^{\infty} \int_{-\infty-\infty}^{\infty} \int_{\left[(x-\alpha)^{2}+(y-\beta)^{2}+(z-\gamma)^{2}\right]^{3 / 2}}^{\Delta} d \alpha \cdot d \beta . d \gamma\right)-(0,308765-0,04193 \rho)\left(h_{2}-h_{1}\right)
$$

pengambilan air tanah oleh manusia dan lain-lain. Perubahan gayaberat akibat adanya dinamika muka air tanah dapat diturunkan dengan melakukan simulasi respon gayaberat mikro terhadap penurunan air muka tanah maupun menggunakan pendekatan koreksi Bouguer sederhana dengan memasukkan variabel porositas [11] :
Keterangan :

$$
\begin{array}{cl}
\Delta \mathrm{gw} \quad \text { : perubahan nilai gravitasi } \\
\\
\text { karena adanya perubahan } \\
\text { tinggi air tanah } \\
\rho \quad \text { : densitas fluida }(\mathrm{gr} / \mathrm{cc})
\end{array}
$$




\begin{abstract}
$g_{w}=2 \pi G \rho \phi h$
$g_{w}=0.041963 \rho \phi h$

$\Delta g_{w}=41.93 \rho \phi h$

Anomali gayaberat mikro 4D merupakan selisih dari nilai pengukuran gayaberat periode Juni 2004 dan Nopember 2005 ( $\left.g_{\text {obs(2) }}-g_{\text {obs(1) }}\right)$, yang disebabkan oleh perubahan tinggi stasiun pengamatan akibat adanya amblesan tanah dan dinamika densitas bawah permukaan akibat dari penambahan dan pengurangan air tanah., dengan asumsi bahwa tidak terjadi penambahan bagunan disekitar titik stasiun pengamatan. Dengan
\end{abstract} persamaan [12]

\section{Keterangan :}

$\begin{array}{ll}\left(\mathrm{g}_{\text {obs }(2)}-\mathrm{g}_{\mathrm{obs}(1)}\right) & \begin{array}{l}: \text { gayaberat pengukuran } \\ (\mathrm{mGal})\end{array} \\ \mathrm{G} & : \text { konstanta gayaberat } \\ & \text { universal }\left(6.673 \times 10^{-11} \mathrm{~m}^{3}\right. \\ & \left.\mathrm{kg}^{-1} \mathrm{~s}^{-2}\right) \\ & : \text { kontras densitas }\left(\mathrm{g} / \mathrm{cm}^{3}\right) \\ \Delta \rho & : \text { koordinat densitas }(\mathrm{m}) \\ (\alpha, \beta, \gamma) & : \text { koordinat stasiun } \\ (\mathrm{x}, \mathrm{y}, \mathrm{z}) & \text { pengamatan }(\mathrm{m})\end{array}$

terletak di tengah daerah penelitian (warna abuabu), sedangkan daerah yang bernilai positip (warna merah) menempati sebelah barat laut diidentifikasikan adanya imbuhan air tanah dan
$\begin{array}{ll}\Delta \mathrm{t} & : \text { selang waktu pengukuran } \\ \mathrm{h} & : \text { tinggi }(\mathrm{m})\end{array}$

\section{HASIL DAN PEMBAHASAN}

Anomali gayaberat mikro 4D selama selang waktu tersebut ada yang bernilai positif dan negatif. Anomali positif (+) berhubungan dengan penambahan air tanah dan amblesan tanah (landsubsidence) dalam selang waktu tersebut. Sedangkan anomali negatif (-) berhubungan dengan pengurangan massa air tanah (penurunan muka air tanah).

Pada gambar 5, menunjukan bahwa hampir $80 \%$ daerah penelitian memiliki anomali gayaberat mikro 4D negatif, hal ini menunjukkan bahwa respon gayaberat akibat pengurangan airtanah lebih besar dibandingkan dengan respon gayaberat akibat amblesan. Daerah dengan nilai anomali gayaberat negatif besar terletak di sebelah utara dan di barat laut (warna hijau) daerah penelitian (Gambar 5). Dikarenakan pada daerah penelitian adalah daerah industri dan melakukan pengambilan air cukup banyak. Anomali gayaberat mikro 4D yang mendekati nol (0) menunjukkan bahwa daerah tersebut stabil atau respon amblesan tanah hampir sama dengan respon penurunan air tanah. Daerah dengan nilai anomali gayaberat mendekati nol

amblesan, hal ini bisa disebabkan oleh adanya rob (banjir genangan yang masuk dari arah laut (utara). 


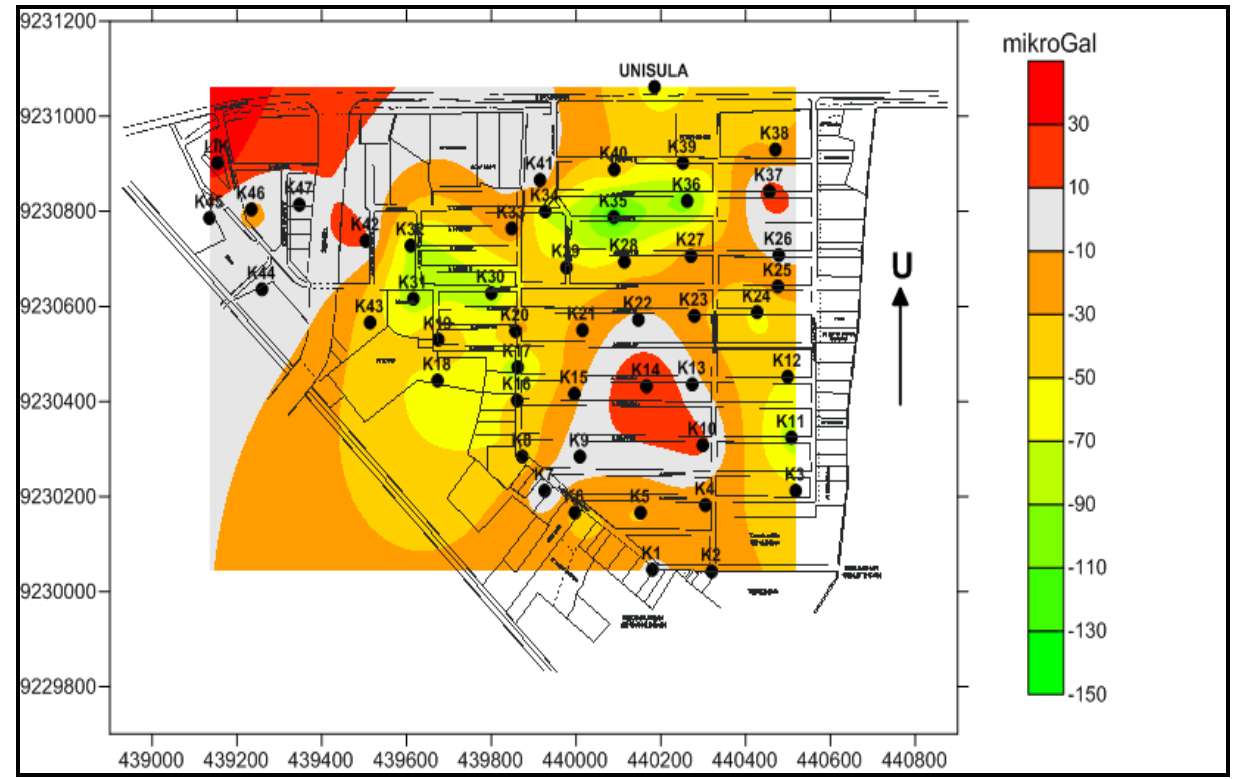

Gambar 5. Peta Anomali gayaberat mikro antar waktu Periode Juni 2004 - Nopember 2005 Daerah Industri Kaligawe Semarang.

Gambar 6 memperlihatkan peta anomali gradien vertikal gayaberat 4D Periode Juni 2004 Nopember 2005 dimana gradien vertikal gayaberat berperan untuk mempertegas struktur anomali karena sifatnya meningkatkan kontras anomali [13]. Dari peta tersebut dapat dikatakan

Anomali gradien vertikal gayaberat $4 \mathrm{D}$ negatif tinggi berwarna hijau (-50 s/d $-90 \mu \mathrm{Gal} / \mathrm{m})$, menunjukan penurunan muka airtanah yang besar. Keadaan ini terjadi di sebelah utara dan melebar ke arah barat daerah penelitian. Anomali gradien vertikal gayaberat 4D negatif rendah berwarna biru (0 s/d -30 $\mu \mathrm{Gal} / \mathrm{m})$, menunjukan penurunan muka air sedang. Terjadi disebelah tengah dan melebar ke utara dan ke arah barat. Anomali misalnya untuk kebutuhan industri. dimana pengurangan massa air (penurunan muka air tanah) ditunjukan dengan harga gradien vertikal gayaberat 4D negatif besar, imbuhan airtanah ditunjukan oleh anomali gradien vertikal gayaberat 4D positif besar, dan batas-batas anomali ditunjukan oleh harga mendekati nol. gradien vertikal gayaberat $4 \mathrm{D}$ positif tinggi berwarna merah $(+50$ s/d $+90 \mu \mathrm{Gal})$, menunjukan terjadi imbuhan air tanah. Imbuhan air tanah dapat berasal imbuhan dari saluran air (influent stream) dan rob ini terjadi disebelah timur dan tengah daerah penelitian. Anomali gradien vertikal gayaberat $4 \mathrm{D}$ ini secara umum terkait langsung dengan pola pengambilan air tanah di daerah tersebut, 


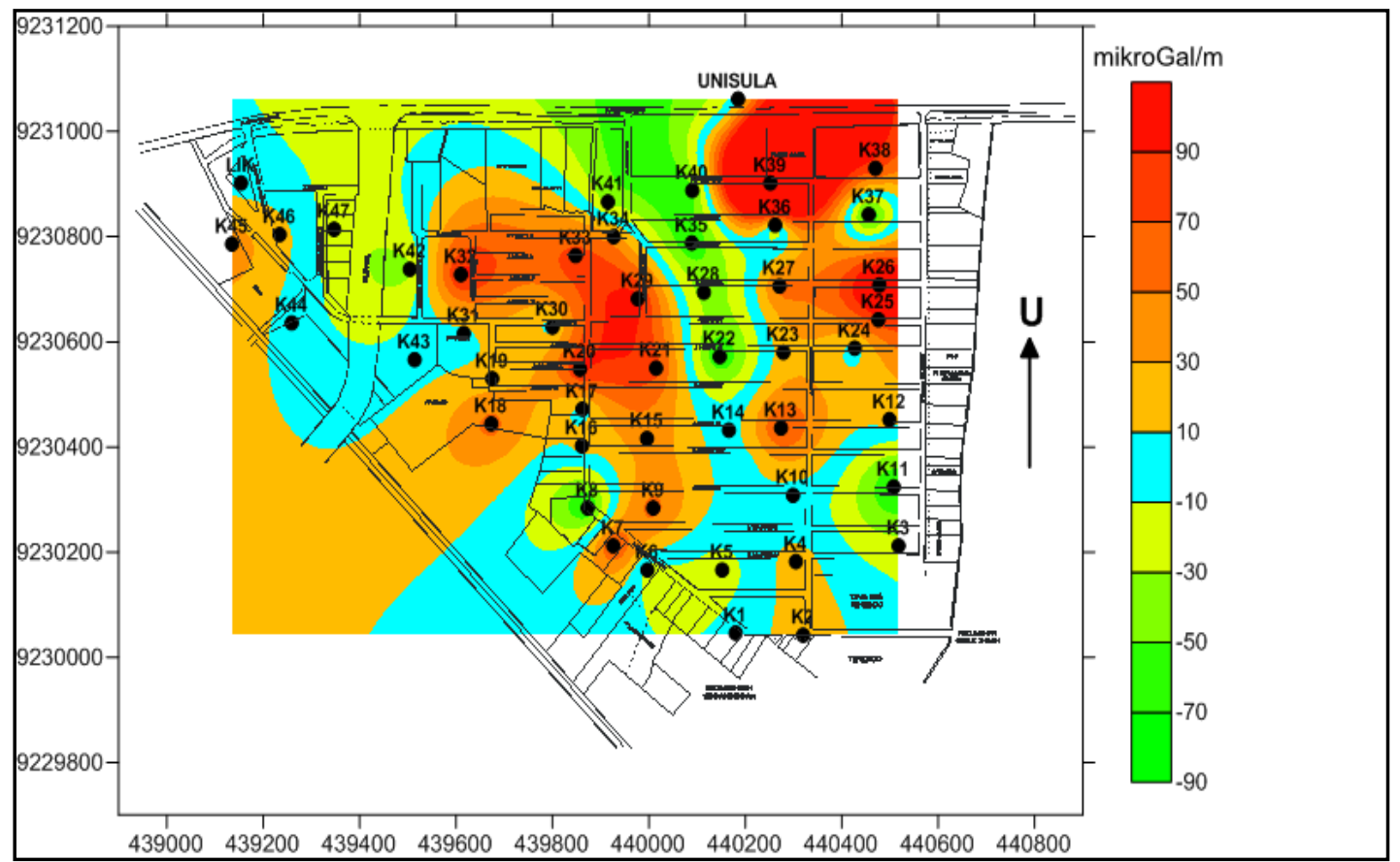

Gambar 6. Peta Anomali gradien vertikal gayaberat antar waktu Periode Juni 2004 - Nopember 2005 Daerah Industri Kaligawe Semarang.

Peta penurunan muka tanah (Gambar 7) menunjukkan bahwa daerah dengan nilai penurunan muka tanah tinggi berwarna merah (6$10 \mathrm{~cm} / 16 \mathrm{bln})$ terjadi di sebelah tengah, utara, selatan dan melebar ke arah barat. Daerah dengan nilai penurunan muka tanah sedang berwarna kuning $(2-6 \mathrm{~cm} / 16$ bln $)$ terjadi di sebelah tengah. Sedangkan daerah dengan penurunan muka tanah relatif rendah berwarna hijau $(1-2 \mathrm{~cm} / 16 \mathrm{bln})$ terjadi disebelah tengah daerah penelitian

Hasil dari pengukuran ini memperlihatkan bahwa penurunan muka tanah memiliki nilai yang bervariasi berkisar antara $1-10 \mathrm{~cm}$ dan memusat ke sebelah tengah (warna merah) penurunan muka tanah terbesar terjadi di titik K14 dan mengarah ke bagian Selatan yaitu sekitar 5-9 cm (Gambar 5), sedangkan di bagian Barat penurunannya berkisar dari 2-7 $\mathrm{cm}$. Pola penurunan muka tanah yang terjadi cenderung melebar ke arah Barat.

Untuk lebih memperjelas zona-zona yang mengalami penurunan muka airtanah, imbuhan airtanah, atau amblesan ini, maka dilakukan analisa dari peta gayaberat mikro $4 \mathrm{D}$, peta gradien vertikal gayaberat $4 \mathrm{D}$ dan peta amblesan tanah. Dengan menggunakan Tabel 1 maka akan dibuat peta kompilasi antara peta gayaberat mikro 4D dan peta gradien-vertikal gayaberat 4D akan menghasilkan suatu peta zonasi yang akan mengambarkan perubahan-perubahan yang terjadi di daerah industri Kaligawe - Semarang.

Interpretasi dengan tiga peta ini secara terpadu diperlukan karena keterbatasan masing-masing respon anomali, misalnya anomali gayaberatmikro 
antar waktu merupakan respon keseluruhan dari dinamika airtanah dan amblesan atau kenaikan permukaan tanah (Gambar 5). Sedangkan anomali gradien vertikal gayaberat antar waktu (Gambar 6) hanya respon dari dinamika airtanah saja, amblesannya tidak termasuk didalamnya. Dari gabungan antara peta anomali gayaberatmikro antar waktu dan peta anomali gradien vertikal gayaberat antar waktu akan dihasilkan peta zonasi (Gambar 8) yang memperlihatkan dinamika perubahan muka air tanah di kawasan industri Kaligawe - Semarang selang waktu Juni 2004 Nopember 2005

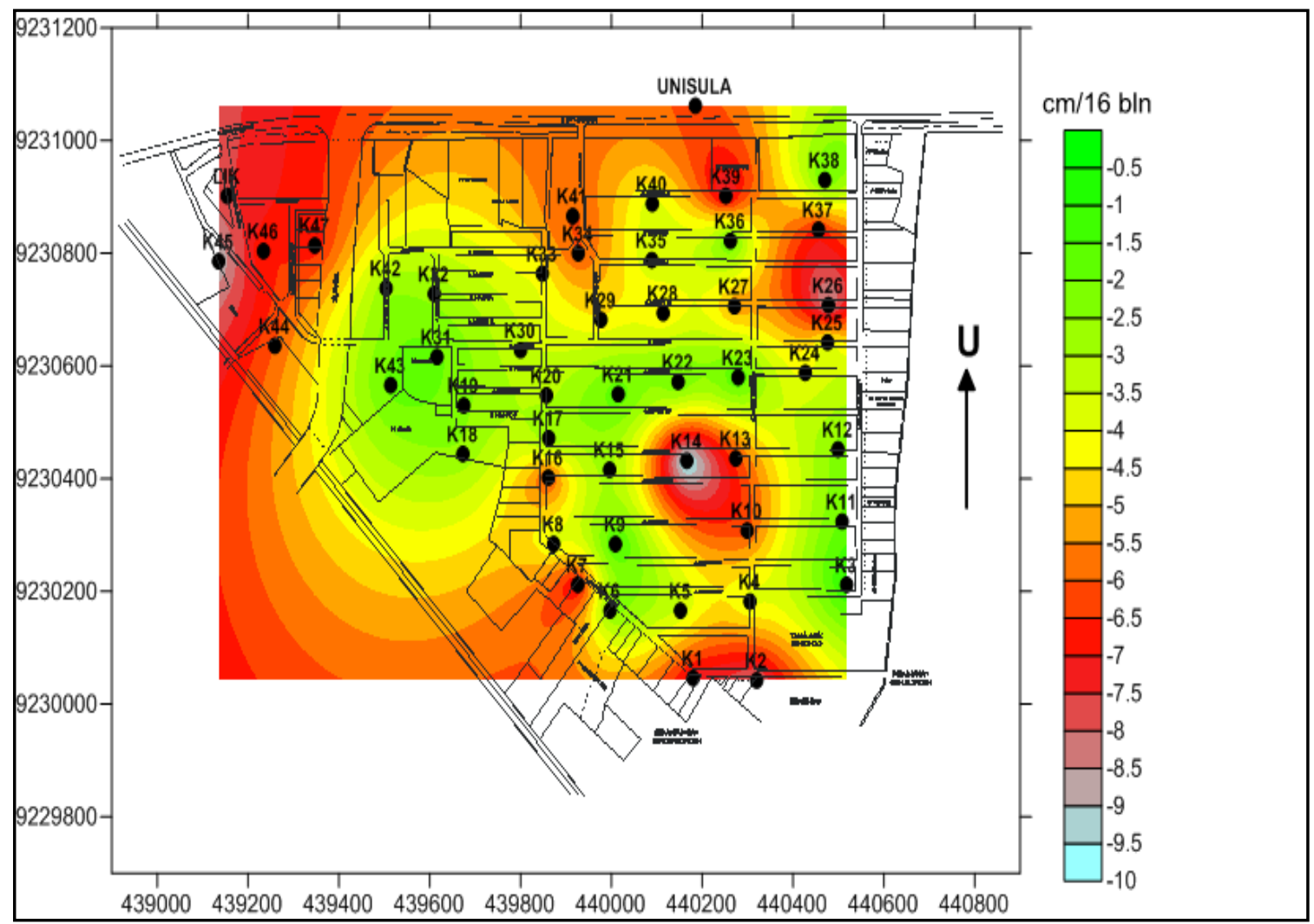

Gambar 7. Peta amblesan tanah periode Juni 2004 - Nopember 2005 Daerah Industri Kaligawe Semarang 
Tabel 1. Kombinasi anomali gayaberatmikro 4D dan anomali gradien vertikal gayaberat 4D [14].

\begin{tabular}{|c|c|c|l|}
\hline No & $\begin{array}{c}\text { Nilai gayaberat } \\
\text { mikro 4D }(\mu \mathrm{Gal})\end{array}$ & $\begin{array}{c}\text { Nilai gradien vertikal } \\
\text { gayaberat 4D }(\mu \mathrm{Gal})\end{array}$ & \multicolumn{1}{|c|}{ Sumber Anomali } \\
\hline 1 & $(+)$ & $(+)$ & $\begin{array}{l}\text { Amblesan dan peningkatan } \\
\text { massa bawah permukaan } \\
\text { tanah atau hanya } \\
\text { peningkatan massa bawah } \\
\text { permukaan tanah }\end{array}$ \\
\hline 2 & $(+)$ & $(0)$ & Hanya Amblesan \\
\hline 3 & $(+)$ & $(-)$ & $\begin{array}{l}\text { Pengurangan massa bawah } \\
\text { permukaan tanah dan } \\
\text { amblesan (dominan) }\end{array}$ \\
\hline 4 & $(-)$ & $(-)$ & $\begin{array}{l}\text { Hanya pengurangan massa } \\
\text { bawah permukaan tanah }\end{array}$ \\
\hline 5 & $(0)$ & $(-)$ & $\begin{array}{l}\text { Pengurangan massa bawah } \\
\text { permukaan tanah sama } \\
\text { dengan amblesan }\end{array}$ \\
\hline
\end{tabular}

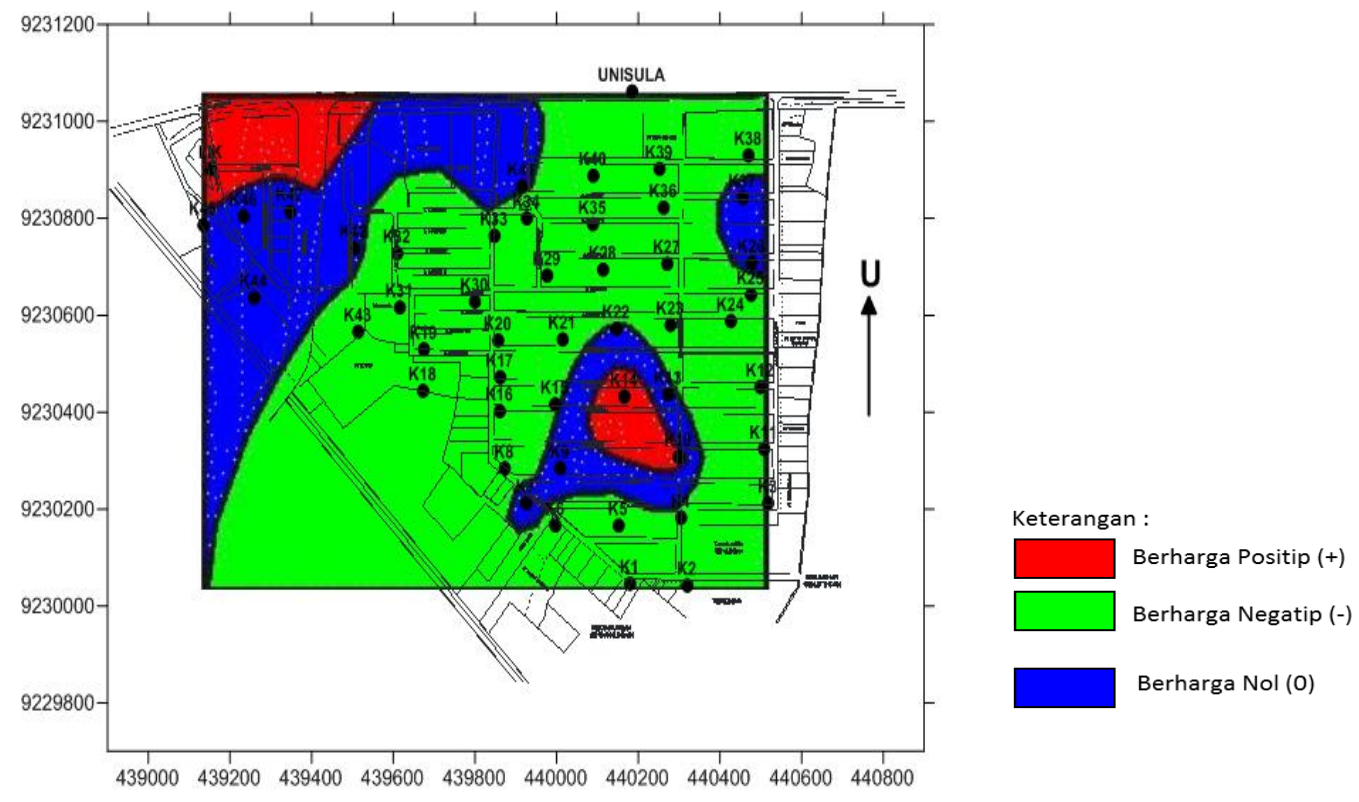

Gambar 8. Peta zonasi gayaberat mikro 4D periode Juni 2004 - Nopember 2005 Daerah Industri Kaligawe Semarang

Zonasi Penurunan Muka Air Tanah di Wilayah Pesisir Berdasarkan Teknik Geofisika Gaya berat Mikro 4D (Studi Kasus: Daerah Industri Kaligawe - Semarang) - Dino Gunawan Pryambodo dan Supriyadi 


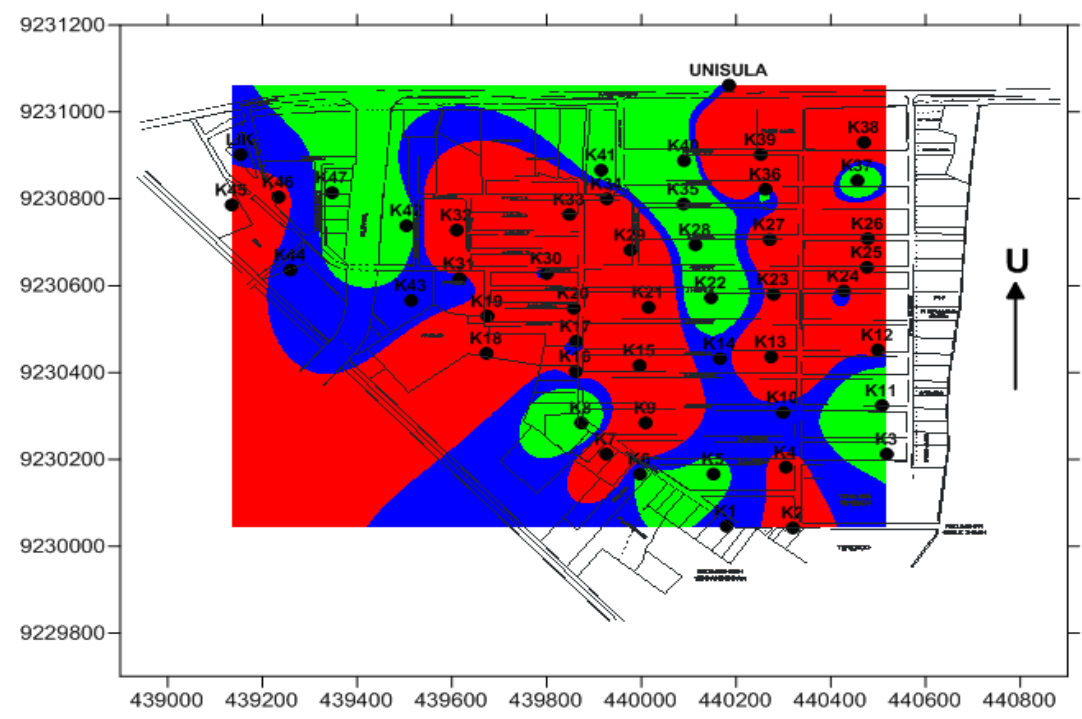

Gambar 9. Peta zonasi Gradien vertikal gayaberat 4D periode Juni 2004 - Nopember 2005 Daerah Industri Kaligawe - Semarang

Keterangan :

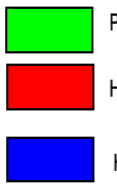

Penurunan Muka Air Tanah dan amblesan Tanah

Hanya Penurunan Muka Air Tanah

Hanya Amblesan Tanah

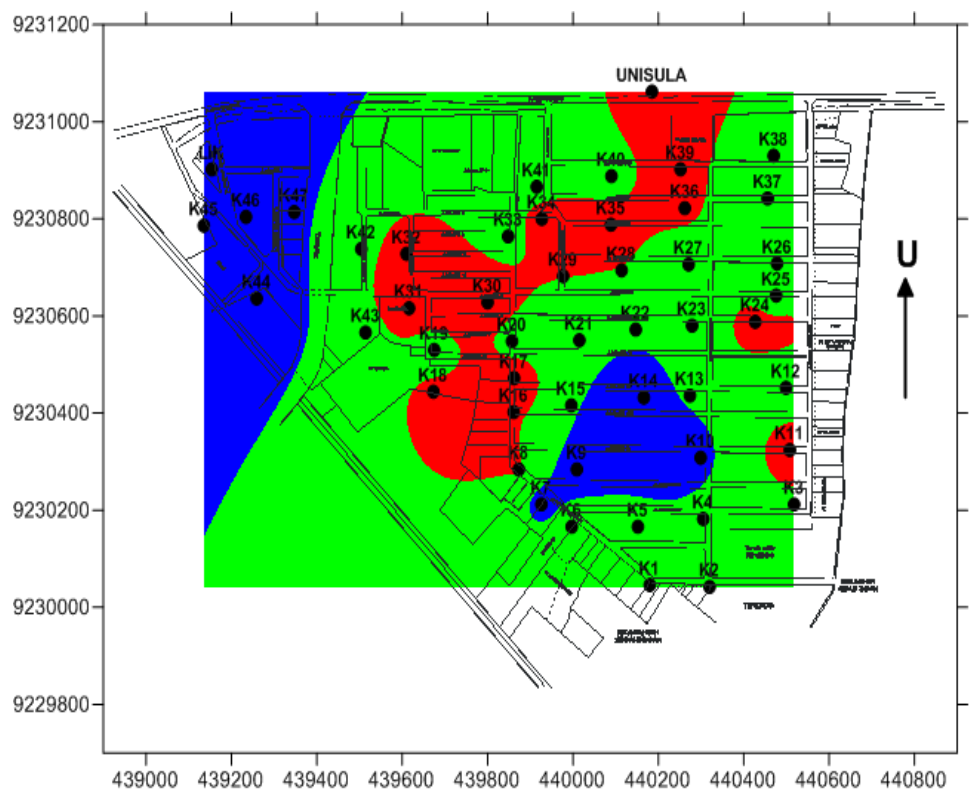

JURNAL KELAUTAN NASIONAL, Vol. 10, No. 3, Desember 2015, Hal. 151-162 
Gambar 10. Peta zonasi penurunan muka air tanah periode Juni 2004 - Nopember 2005 Daerah Industri Kaligawe - Semarang

Dari peta zonasi yang telah dibuat dapat diketahui bahwa hampir $70 \%$ daerah penelitian mengalami penurunan muka air tanah dan amblesan tanah dengan waktu yang hampir bersamaan, hal ini disebabkan karena perkembangan pengambilan air tanah yang pesat di daerah ini dan mengakibatkan perubahan kondisi dan lingkungan air tanah, sebagai pencerminan terjadinya kerusakan tata airtanah dengan beberapa kualitas air sumur penduduk yang berubah menjadi payau [4]. Buktibukti yang menunjukkan adanya penurunan muka air tanah perubahan tersebut diantaranya: 1 . Terjadinya amblesan tanah di daerah penelitian [15]; 2. Keadaan tinggi air tanah yang terdapat dalam sumur pantau yang terus mengalami penurunan [16] seperti yang di tunjukkan pada Gambar 3. Meskipun faktor penyebab utama belum diketahui secara pasti, namun faktor penurunan muka air tanah akibat pengambilan air tanah yang berlebihan untuk keperluan industri, diyakini ikut berperan dalam penurunan muka air tanah, karena di daerah industri Kaligawe terdapat beberapa perusahaan yang bergerak di bidang garmen, pengolahan hasil laut, produk makanan dan otomotif [17].

Untuk mencegah penurunan muka airtanah lebih lanjut di daerah industri Kaligawe - Semarang maka perlu diadakannya pengisisan airtanah (ground water recharge) yang berguna untuk menanggulangi defisit airtanah, telah bayak pemikir yang mengajukan konsep pengisian buatan (artificial recharge), misalnya dengan membuat lubang resapan biopori disekitar rumah. Untuk daerah pesisir pengisian airtanah buatan mempunyai kegunaan sebagai berikut [18]:

1. Menyimpan kelebihan air permukaan di dalam akuifer.

2. Memperbaiki kualitas airtanah lokal melalui percampuran dengan pengisian airtanah yang berasal dari air hujan.

3. Pembantukan tabir tekanan (pressure barriers) untuk mencegah intrusi air asin.

4. Meningkatkan produksi airtanah, baik untuk diminum maupun untuk keperluan lainnya.

5. Pengurangan biaya operasi pompa dengan meningginya muka airtanah.
6. Mencegah terjadinya penurunan muka tanah (land subsidence).

\section{KESIMPULAN DAN SARAN}

Dengan memadukan metoda gayaberat mikro 4D dan gradien vertikal gayaberat 4D akan memiliki karakteristik dalam memberikan informasi anomali yang diberikan sehingga dapat digunakan untuk membantu dalam intrepretasi. Dalam kasus penurunan muka airtanah didaerah industri Kaligawe - Semarang menunjukkan bahwa pengunaan gayaberat mikro 4D dan gradien vertikal gayaberat 4D secara bersamaan dapat membatu dalam proses intrepretasi sehingga dapat diketahui batas-batas anomali dimana memberikan informasi zona-zona penurunan muka air tanah dan amblesan, dan hampir $70 \%$ daerah penelitian mengalami penurunan muka airtanah dan amblesan, hal ini didukung dengan adanya penurunan muka airtanah dari beberapa sumur pantau yang ada di sekitar daerah penelitian.

\section{DAFTAR PUSTAKA}

[1]. Abidin, H. Z., Andreas, H., Gumilar, I., Sidiq, T.P., Gamal, M., Murdohardono, D., et. al. (2010). Studying Land Subsidence in Semarang (Indonesia) Using Geodetic Methods, FIG Congress Facing the Challenges - Building the Capacity, Sydney, Australia

[2]. Bemmelen, R.W. (1949). The Geology of Indonesia, Vol. IA. General Geology, Government Printing Office: The Hague, $732 \mathrm{~h}$.

[3]. Putranto, T, T., \& Rüde, T, R. (2011). Groundwater Problems in Semarang Demak Urban Area, Java/Indonesia, RWTH Aachen University, Institute of Hydrogeology, Germany

[4]. Suhartono, E., Purwanto, \& Suripin. (2013). Kondisi Intrusi Air Laut Terhadap Air 
Tanah Pada Akuifer di Kota Semarang, Prosiding Seminar Nasional Pengelolaan Sumberdaya Alam dan Lingkungan, Universitas Diponegoro, Semarang

[5]. Sihwanto, \& Iskandar, N. (2000). Konservasi Airtanah Daerah Semarang dan Sekitarnya, DGTL, Bandung.

[6]. Taufiq, A.N. (2010). Penyelidikan Konservasi Air Tanah Cekungan Air Tanah Semarang -Demak Provinsi Jawa Tengah, 145/LAP BGE. P2K/2010. Kementrian ESDM, Badan Geologi, Pusat Lingkungan Geologi

[7]. Marsudi, 2000., Prediksi Laju Amblesan Tanah di Dataran Alluvial Semarang Propinsi Jawa Tengah, Disertasi Program Pascasarjana ITB.

[8].Lacoste \& Romberg, 2004, Instruction Manual Model G \& D Gravity Meters, Austin, Texas USA.

[9].Supriyadi. (2009). Studi Gaya Berat Relatif Di Semarang, Jurnal Pend. Fisika Indonesia Vol.5, No. 1. Semarang

[10].Allis, R.G., \& Hunt, T.M. (1986). Analisis of Exploration-Induced Gravity Changes at Wairakei Geothermal Field, Geophysics 51, p. 1647-1660.

[11]. Sarkowi M., Kadir W.G.A., \& Santoso, D. (2003). Monitoring Dinamika Air Tanah Daerah Semarang dengan Metode Gayaberat Mikro-4D, Jurnal Geofisika, N0.1, p. 1-8.

[12].Dahrin, D., Sarkowi, M., Kadir, W.G.A., \& Minardi, S. (2007). Penurunan Volume Airtanah Daerah Semarang berdasarkan Pemodelan 3D Gayaberat Antar Waktu. Jurnal Geoaplika, (2)1:11-17

[13].Sarkowi, M., Supriadi. (2012). Metode Gradien Vertikal Gayaberat Mikro Antar Waktu Dan Aplikasinya. Proceeding SEMINAR NASIONAL FISIKA TERAPAN III Surabaya

[14].Kadir, W.G.A., Santoso, D., \& Sarkowi, M. (2004). Time Lapse Vertical Gradient Microgravity Measurement for Subsurface
Mass Change and Vertical Ground Movement (Subsidence) Identification, Case Study : Semarang alluvial plain, central Java, Indonesia, Proceedings of the $7^{\text {th }}$ SEGJ International Symposium, Sendai Japan.

[15].Yuwono, B.D. (2013). Korelasi Penurunan Muka Tanah Dengan Penurunan Muka Air Tanah di Kota Semarang, Jurnal TEKNIK, Vol.34 No. 3, UNDIP Semarang.

[16]. Setiana, M. (2013). Metode Gradien Vertikal Gayaberat Antar Waktu Untuk Pemantauan Dinamika Airtanah di Kota Semarang, Skripsi, Jurusan Fisika FMIPA UNNES, Semarang

[17]. Bappeda kota Semarang. (2010). Statistik Industri Besar dan Sedang Kota Semarang, Semarang

[18]. Triadi. T., \& Indra. K. (2009). Permasalahan Airtanah Pada Daerah Urban, Jurnal TEKNIK, Vol. 30, No. 1. SEMARANG 